Archive for

Arkivoc 2017, part v, 89-99

Organic Chemistry

\title{
Synthesis and conformational analysis of novel tertiary amides derived from $N$-[(S)- $\alpha$-phenylethyl]-1,3-Imidazolidine
}

Ericka Santacruz-Juárez, ${ }^{\mathrm{a}, \mathrm{b}^{*}}$ Herbert Höpfl, ${ }^{\mathrm{d}}$ Gabriela Huelgas, ${ }^{\mathrm{a}}$ Oscar Romero, ${ }^{\mathrm{b}}$ Alejandro Castro, ${ }^{\mathrm{b}}$ Cecilia Anaya de Parrodi, ${ }^{a *}$ Sharity Morales-Meza, ${ }^{\mathrm{e}}$ and Mario Sanchez ${ }^{\mathrm{e}}$

${ }^{a}$ Departamento de Química y Biología, Universidad de las Américas-Puebla, Santa Catarina Mártir, CP 72820 , Cholula, México

${ }^{b}$ Universidad Politécnica de Tlaxcala, Av. Universidad Politécnica de Tlaxcala No.1, San Pedro Xalcaltzinco Municipio de Tepeyanco, CP 90180, Tlaxcala, México

'Departamento de Química, Centro de Investigación y Estudios Avanzados del Instituto Politécnico Nacional, CP 07000, México, D. F., México

${ }^{d}$ Centro de Investigaciones Químicas, Instituto de Ciencias Básicas y Aplicadas, Universidad Autónoma del Estado de Morelos, Av. Universidad 1001, CP 62209, Cuernavaca, México

${ }^{e}$ Centro de Investigación en Materiales Avanzados S.C. Alianza Norte 202, PIIT, Carretera Monterrey

Aeropuerto Km 10 CP 66628, Apodaca NL., México

E-mail : ericka.santacruz@uptlax.edu.mx

Received 01-13-2017

Accepted 06-18-2017

Published on line $07-21-2017$

\section{Abstract}

The synthesis of three chiral tertiary amides by ring opening of the symmetric 1,3-imidazolidine 2 under mild conditions is described. ${ }^{1} \mathrm{H}$ NMR dynamics studies were performed to identify three rotamers present in solution, which were also examined by DFT calculations.
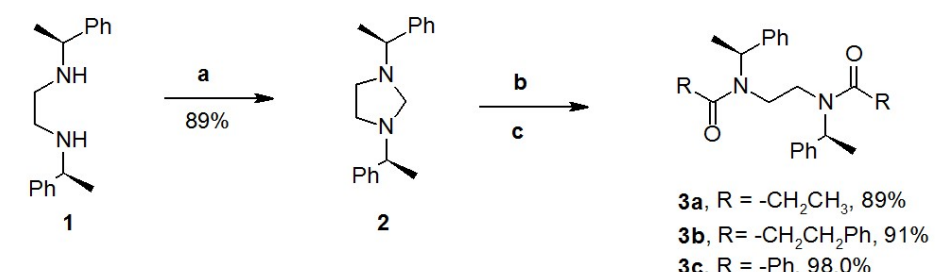

Reagents and conditions: a) $\mathrm{K}_{2} \mathrm{CO}_{3} / \mathrm{MgSO}_{4} / \mathrm{CHCl}_{3}, \mathrm{CH}_{2} \mathrm{O}-\mathrm{H}_{2} \mathrm{O}(37 \% \mathrm{v} / \mathrm{N})$.

b) $n$-BuLi (1.2 equiv), $0{ }^{\circ} \mathrm{C}, \mathrm{c}$ ) RCOCl (2.2 equiv), $-78^{\circ} \mathrm{C}$

Keywords: Tertiary amides, variable temperature RMN, theoretical analysis, Z- and E-rotamer 
Amide bond formation is one of the most often used transformations in organic synthesis, and amides are frequently employed as building blocks for the synthesis of biologically active compounds ${ }^{1-3}$ such as antiinflammatory and analgesic agents, ${ }^{4,5}$ fungicides antibiotics, parasiticides and antivirals. ${ }^{6,7}$ The synthetic route used most frequently for amide formation involves the combination of an amine (including ammonia) with an activated carboxylic acid derivatives ${ }^{8}$ or directly with the carboxylic acid in a reaction mediated by a coupling reagent. ${ }^{9}$ The existing methods have several drawbacks in common, such as poor atom-efficiency, the use of hazardous reagents, and the generation of waste that not only reduce the process efficiency but also impose environmental problems. To address these challenging problems in amide synthesis, a plethora of novel amide formation reactions have been developed, ${ }^{10}$ i.e. catalytic acylation of amines with carboxylic acids, ${ }^{11}$ dehydrogenative amidation of alcohols, ${ }^{12-14}$ amino carbonylation of aryl chlorides, ${ }^{15,16}$ hydroamination of alkynes, ${ }^{17,18}$ transamidation of primary amides, ${ }^{19,20}$ and oxidative amidation of aldehydes. ${ }^{21,22}$

Fife and Perillo have reported a ring-opening reaction starting from 1,3-imidazolidines via acid catalysis and a mechanism has been proposed. ${ }^{23}$ The structural features of amides have been widely studied by NMR spectroscopy and molecular modeling studies, among others because they represent model compounds for peptides and proteins. ${ }^{24-26}$

As part of an ongoing project involving chiral diamines as chiral ligand adjuvants, ${ }^{27,28}$ herein we have also examined the $E / Z$ equilibrium of tertiary amides 3a-3c, which were prepared by a ring-opening reaction of 1,3imidazolidine $\mathbf{2}$ with $n$-BuLi and different acyl chlorides.

\section{Results and Discussion}

A series of convenient procedures for the preparation of $N, N^{\prime}$-ethylene-bis[(S)-1-phenylethyl]amine 1 are available in the literature. ${ }^{29}$ Accordingly, 1,3-imidazolidine 2 was prepared in excellent yield (98\%) by condensation of diamine 1 with aqueous formaldehyde following the general procedure reported by Coldham et $a .^{30,31}$ (Scheme 1). An important observation for this reaction is that the use of formaldehyde (37\% aq. v/v) instead of paraformaldehyde resulted in higher yields ( $98 \%$ versus $80 \%$ ).

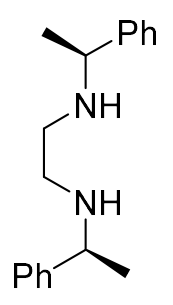

1

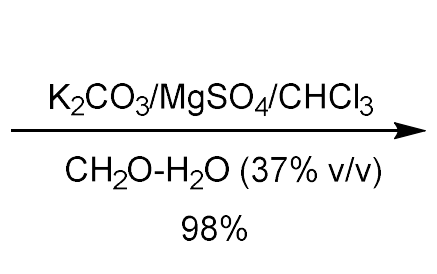

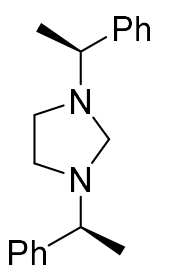

2

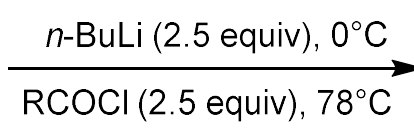

3a, $\mathrm{R}=-\mathrm{CH}_{2} \mathrm{CH}_{3}, 89 \%$

3b, $\mathrm{R}=-\mathrm{CH}_{2} \mathrm{CH}_{2} \mathrm{Ph}, 91 \%$

3c, $\mathrm{R}=-\mathrm{Ph}, 98 \%$

Scheme 1. Reaction sequence for the synthesis of 3a-3c.

For the ring-opening reaction of 1,3-imidazolidine 2, with a series of different bases were tested, including secBuLi (1.2 equiv), NaHMDS (1.2 equiv), DBU (1.2 equiv), DMPA (1.2 equiv), DMPA-Et ${ }_{3} \mathrm{~N}$ (0.05:1.3), and Py (1.2 equiv). The optimal conditions for the preparation of 3a-3c were observed in the presence of $n$-BuLi ( 2.5 
equiv, $1.0 \mathrm{M}$ solution in hexane). ${ }^{32}$ After the addition of $n$-BuLi at $0{ }^{\circ} \mathrm{C}$ the reaction mixture was stirred for 0.5 h, whereupon 2.5 equivalents of the corresponding acyl chloride (propionyl, hydrocinamoyl and benzoyl chloride) were added at $-78{ }^{\circ} \mathrm{C}$. After chromatographic purification, the tertiary amides $3 \mathrm{a}-\mathbf{3 c}$ were afforded in yields ranging from 89 to $98 \%$ (Scheme 1 ).<smiles>CCC(=O)N(CCN(C(=O)CC)[C@H](C)c1ccccc1)[C@@H](C)c1ccccc1</smiles>

Z-syn<smiles>CCC(=O)N(CCN(C(=O)CC)[C@@H](C)c1ccccc1)[C@@H](C)c1ccccc1</smiles>

Z-anti

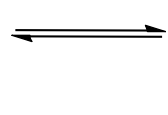

$(1 ' S, 1 " S)-3 a$<smiles>CCC(=O)N(CCN(C(=O)CC)[C@H](C)c1ccccc1)[C@@H](C)c1ccccc1</smiles>

E-syn<smiles>CCC(=O)N(CCN(C(=O)CC)[C@H](C)c1ccccc1)[C@@H](C)c1ccccc1</smiles>

E-anti

Figure 1. Conformational interconversion reactions for compound 3a.

Compounds $3 a-3 c$ are the result of a diacylation reaction of the nitrogen atoms leading to the ring-opening of the imidazolidine ring. This observation indicates that the $\mathrm{C}-\mathrm{N}$ bonds are activated by coordination of the Lewis acid to the nitrogen. ${ }^{33}$

When smaller amounts of acyl chloride were employed, e.g. 1.2 equivalents, the imidazolidine ring opens forming 3a-3c rotamers, but there were still traces of the starting material (2).

Even though, compounds 3a-3c seem to be simple molecules, the ${ }^{1} \mathrm{H}$ and ${ }^{13} \mathrm{C} \mathrm{NMR}$ spectra in $\mathrm{CDCl}_{3}$ at room temperature show the presence of a dynamic equilibrium, giving a total of three sets of signals, which based on HSQC experiment are attributed to rotamers (Z-syn, E-syn, and E-anti, with population ratios of 1.4:1.5:0.3) (Figure 1). Interestingly the Z-anti rotamer was not observed, which was attributed to steric repulsion between the carbonyl group and the phenyl group. Variable temperature ${ }^{1} \mathrm{H}$ NMR spectra were also measured in DMSO- $d_{6}$ in a temperature range from 20 to $175{ }^{\circ} \mathrm{C}$. In order to assign all signals unequivocally, COSY and HETCOR experiments were realized also at $175^{\circ} \mathrm{C}$ (see Table 1 ).

In order to examine with more detail of the different rotamers present in solution, we explored the potential energy surface of 3a by quantum mechanical DFT calculations, using the B3LYP/6-31G(d,p) method to optimize the geometries and to calculate the relative energies of all minima (see Figure 2). Of the four possible rotamers three (3a-1, 3a-2 and 3a-3) had similar energy values, (Figure 2), which is in agreement with the NMR data. Rotamer 3a-4 has a significantly higher energy $(4.79 \mathrm{kcal} / \mathrm{mol})$ when compared to the most stable conformer 3a-1. 
Table 1. VT NMR experiments for the analysis of rotamers $3 a-3 c$ in $\mathrm{CDCl}_{3}$ and DMSO- $d_{6}$

\begin{tabular}{|c|c|c|c|c|}
\hline Compound & $R$ & Solvent & $\mathrm{T}(\stackrel{\mathrm{o}}{\mathrm{C}})$ & $\begin{array}{c}\text { Ratio } \\
\text { Z-syn, E-syn, E-anti }\end{array}$ \\
\hline \multirow[t]{3}{*}{$3 a$} & $-\mathrm{CH}_{2} \mathrm{CH}_{3}$ & DMSO-d 6 & 25 & $1.4: 1.5: 0.3$ \\
\hline & & DMSO- $d_{6}$ & 170 & $2: 1: 0$ \\
\hline & & $\mathrm{CDCl}_{3}$ & -60 & $1: 1$ \\
\hline \multirow[t]{3}{*}{$3 b$} & $-\mathrm{CH}_{2} \mathrm{CH}_{2} \mathrm{Ph}$ & DMSO- $d_{6}$ & 25 & $1.4: 1.5: 0.3$ \\
\hline & & DMSO- $d_{6}$ & 170 & $2: 1: 0$ \\
\hline & & $\mathrm{CDCl}_{3}$ & -60 & $1: 1$ \\
\hline \multirow[t]{3}{*}{$3 c$} & $-\mathrm{Ph}$ & DMSO- $d_{6}$ & 25 & $1: 0: 0$ \\
\hline & & DMSO- $d_{6}$ & 75 & $1: 0: 0$ \\
\hline & & $\mathrm{CDCl}_{3}$ & -50 & 1:0:0 \\
\hline
\end{tabular}

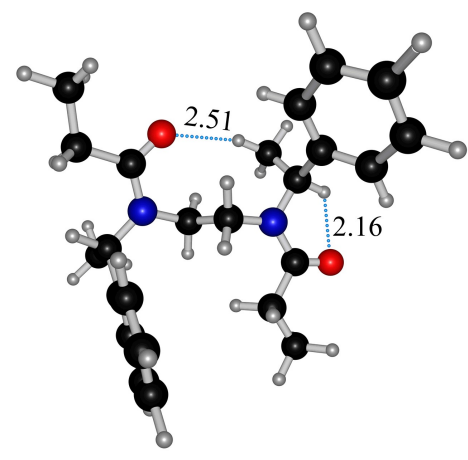

3a-1

$E_{\text {rel }}=\mathbf{0 . 0 0}$

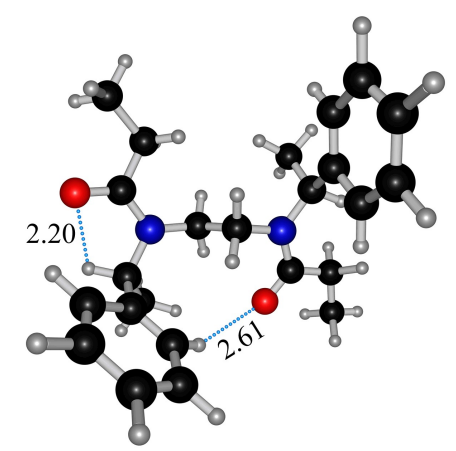

3a-3

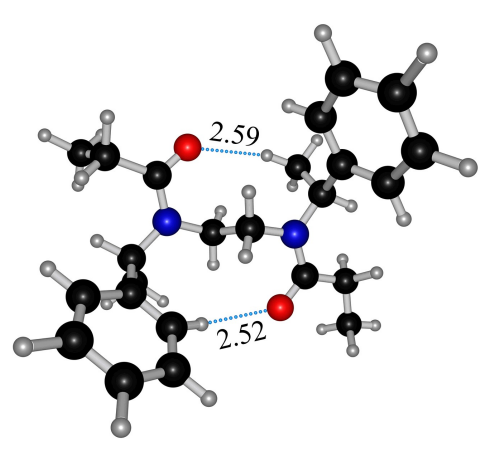

3a-2

$E_{r e l}=1.19$

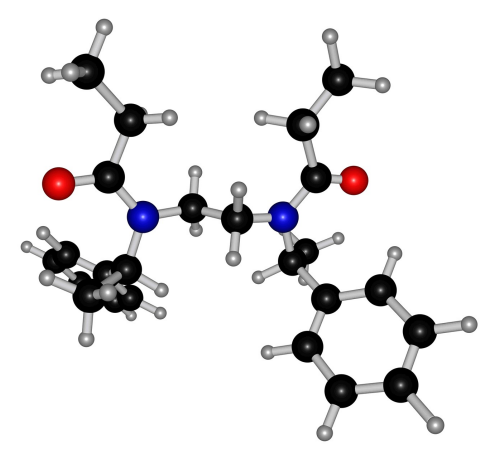

3a-4

$E_{\text {rel }}=4.79$

Figure 2. Optimized geometries for the four possible rotamers of $3 a$ using the B3LYP/6-31G(d,p) method. Relative energies are in $\mathrm{kcal} / \mathrm{mol}$.

The most stable structures 3a-1 and 3a-3, exhibit two type of hydrogen bonds, the first one is between the carbonyl of the amide group and a hydrogen atom attached to the neighboring methine group with $\mathrm{H} \cdots \mathrm{O}$ distances of 2.16 and $2.20 \AA$, respectively, and the second one is in between the carbonyl groups and hydrogen atoms from methyl and phenyl groups, with $\mathrm{H} \cdots \mathrm{O}$ distances of 2.51 and $2.61 \AA$, respectively. On the contrary, 3a-2 showed two $\mathrm{C}-\mathrm{H} \cdots \mathrm{O}$ interactions with hydrogen atoms from phenyl and methyl groups with $\mathrm{H}$... O distances of 2.52 and $2.59 \AA$, which are significantly smaller than the sum of the van der Waals radii ( 2.80 
$\AA$ A). The importance of the $\mathrm{C}-\mathrm{H} \cdots \mathrm{O}$ interactions for the molecular conformation of amides has been previously established also by other research group. ${ }^{34}$

The free energy of activation for the interconversion of compounds 3a-1 to 3a-4 has been investigated by means of dynamic NMR spectroscopy. ${ }^{35,36}$ To measure the free energy of activation $\left(\Delta G^{\neq}\right)$by variable temperature ${ }^{1} \mathrm{H}$ NMR spectroscopy, the coalescence temperature method can be used. The coalescence temperature $\left(T_{c}, \mathrm{~K}\right)$ is the lowest temperature at which the rotamers merge in the ${ }^{1} \mathrm{H}$ NMR spectrum (Table 2 ). The free energy of activation $\left(\Delta G^{\neq}, \mathrm{kcal} \mathrm{mol}^{-1}\right)$ and the rate constant $\left(\mathrm{kc}, \mathrm{s}^{-1}\right)$ can be derived from the Eyring equation (Eqs.1 and 3). ${ }^{36}$

$$
\begin{array}{cccc}
k_{c} & = & \pi \Delta v / \sqrt{2} & {[1]} \\
\Delta G^{\neq} & = & 2.303 R T_{c}\left(10.319+\log \left(T_{c} / k_{c}\right)\right) & {[2]} \\
\Delta G^{\neq} & = & 4.569 \times 10^{-3} T_{c}\left(10.319+\log \left(T_{c} / k_{c}\right)\right) & {[3]}
\end{array}
$$

On the other hand, the rotational barrier for compounds $\mathbf{3 a}$ and $\mathbf{3} \mathbf{b}$ has been calculated both experimentally (Table 2 ) and theoretically (Table 3 ). The theoretical values were calculated in the gas phase with and without solvent (see Table 3). No significant changes were observed when comparing the experimental data with the theoretical values.

Table 2. Relative energies (in $\mathrm{kcal} / \mathrm{mol}$ ) of the barriers of interconversion between the diastereomeric conformations of $\mathbf{3 a}$ and $\mathbf{3 b}$, as established by VT-NMR experiments in $\mathrm{CDCl}_{3}$ and DMSO- $d_{6}$

\begin{tabular}{rrccccccc}
\hline Comp. & Solvent & $\delta_{1}(\mathrm{ppm})$ & $\delta_{2}(\mathrm{ppm})$ & $\begin{array}{c}v \\
(\mathrm{~Hz})\end{array}$ & $\begin{array}{c}\mathrm{k}_{\mathrm{c}} \\
\left(\mathrm{s}^{-1}\right)\end{array}$ & $\begin{array}{c}\mathrm{T}_{\mathrm{c}} \\
(\mathrm{K})\end{array}$ & $\Delta G^{\neq}$exp & $\Delta G^{\neq}$calcd \\
\hline 3a & $\mathrm{CDCl}_{3}$ & 1.41 & 1.38 & 6 & 13.31 & 85 & 17.14 & 15.23 \\
3b & $\mathrm{DMSO} d_{6}$ & 1.37 & 1.25 & 24 & 53.28 & 358 & 16.95 & 17.03 \\
\hline
\end{tabular}

Table 3. Relative energies of the barriers of interconversion between the diastereomeric conformations of the $3 \mathbf{a}$ and $\mathbf{3 b}$, calculated at the B3LYP/6-31G(d,p) level of theory. Note: The experimental values are included for comparison

\begin{tabular}{cccc}
\hline Compound & Solvent & $\Delta \mathrm{G}_{\text {calcd }}$ & $\Delta \mathrm{G}^{\neq}$exp \\
\hline 3a & --- & 22.47 & --- \\
3b & --- & 19.36 & --- \\
3a & $\mathrm{CDCl}_{3}$ & 15.23 & 17.14 \\
3b & $\mathrm{DMSO}_{6}$ & 17.03 & 16.95 \\
\hline
\end{tabular}

Additionally, for 3a crystals suitable for single-crystal X-ray diffraction, analysis could be grown, which allowed to establish that the solid state structure contains only one of the three rotamers found in solutions (Z-syn) (Figure 3). 


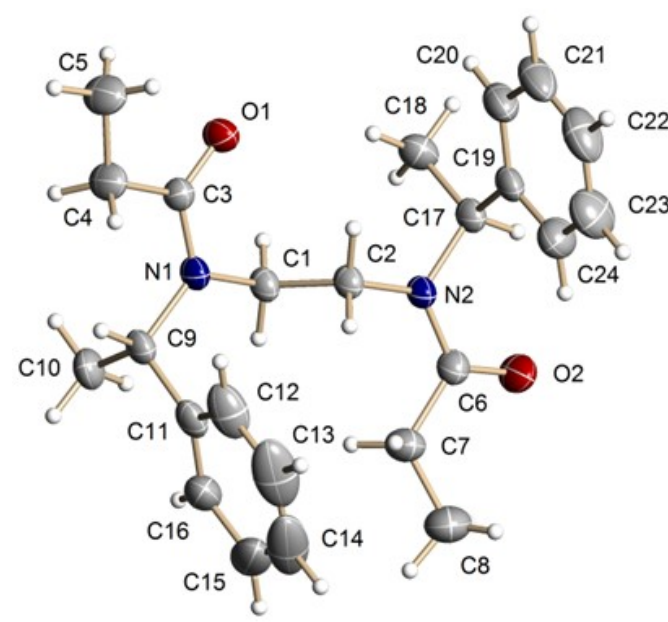<smiles>CCC(=O)N(CCN(C(=O)CC)C(C)c1ccccc1)c1ccccc1</smiles>

(1'S,1"S)-3a

Figure 3. Molecular structure of $N, N^{\prime}$-\{di(propionyl)-di[(S)-1-phenylethyl]\} ethylendiamine 3a established by single crystal $\mathrm{X}$-ray diffraction analysis.

Finally, the molecular structure of $\mathbf{3 c}$ was optimized using the same computational method as described before, giving only one low-ebergy rotamer. In this derivative, the phenyl group attached to the diamide group restricts the rotation of the 1-phenylethyl substituents (Figure 4).

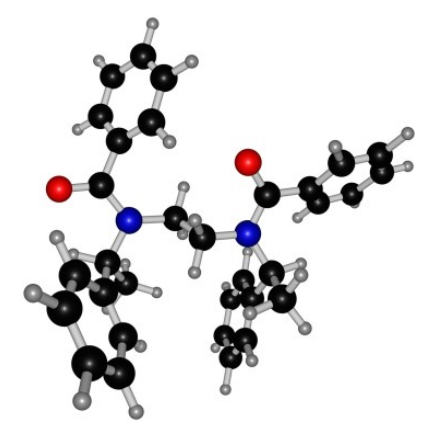

Figure 4. Molecular structure of 3c calculated with the B3LYP/6-31G(d,p) method.

\section{Conclusions}

We reported on the synthesis of chiral symmetrically $N, N^{\prime}$-trisubsituted-1,3-diamides 3a-3c which have been prepared from the corresponding 1,2-diamines in excellent yields (89-98\%). Diacylation of the nitrogen atoms induced ring-opening of 1,3-imidazolidine $\mathbf{2}$ even in the presence of mild bases. The conformational equilibria have been evaluated by VT NMR techniques and DFT calculations, showing that the rate of interconversion between rotamers is almost completely dependent on the nature of the substituent at the amide group.

\section{Experimental Section}

General. All experiments were carried out under an inert $\mathrm{N}_{2}$ atmosphere. THF was distilled from sodium benzophenone. $\mathrm{CH}_{2} \mathrm{Cl}_{2}$ was dried from sodium hydride. Melting points were determined on a Fischer Jones 
apparatus and are uncorrected. Infrared spectra were recorded on a Perkin Elmer 881 spectrophotometer, using polystyrene as reference $\left(1602 \mathrm{~cm}^{-1}\right)$. NMR spectra were obtained on Varian Mercury 200 or 400 equipments. ${ }^{1} \mathrm{H}$ NMR spectra were referenced to tetramethylsilane; ${ }^{13} \mathrm{C}\left\{{ }^{1} \mathrm{H}\right\}$ NMR spectra were referenced to residual non-deuterated solvent.

General Procedure for the Preparation of $N$-[(S)- $\alpha$-phenylethyl]- 1,3-Imidazolidine (2). The $N, N^{\prime}-$ bis $[(1 S)-1$ phenylethyl]ethane-1,2-diamine $(1.81 \mathrm{~g}, 5.62 \mathrm{mmol})$ was added a mixture of $37 \%$ aqueous solution of formaldehyde $(0.30 \mathrm{~mL}, 11.24 \mathrm{mmol}), \mathrm{K}_{2} \mathrm{CO}_{3}(2.00 \mathrm{~g}, 14.6 \mathrm{mmol})$, and $\mathrm{MgSO}_{4}(2.00 \mathrm{~g}, 16.8 \mathrm{mmol})$ in $\mathrm{CHCl}_{3}(25$ $\mathrm{mL}$ ) under inert atmosphere. The reaction mixture was stirred at room temperature for $24 \mathrm{~h}$ and then extracted with $\mathrm{CH}_{2} \mathrm{Cl}_{2}(3 \times 15 \mathrm{~mL})$. The combined organic layer was dried with $\mathrm{Na}_{2} \mathrm{SO}_{4}$, filtered and evaporated under reduced pressure. The crude product was purified by column chromatography on silica gel [hexaneEtOAc; (10:1)].

General Procedure for Ring Opening of Imidazolidine (2). Imidazolidine $\mathbf{2}$ (0.3 g, $1.06 \mathrm{mmol}$ ) was placed in a dry two-necked flask fitted with a condenser and magnetic stirrer in THF under argon atmosphere. The reaction mixture was cooled to $0{ }^{\circ} \mathrm{C}$ on an ice bath, whereupon $n$-BuLi ( $0.66 \mathrm{~mL}, 1.6 \mathrm{M}$ in cyclohexane) was added dropwise. After stirring for $30 \mathrm{~min}$, the reaction mixture was cooled to $-78^{\circ} \mathrm{C}$. Then acyl chloride $(2.33$ mmol) was added dropwise. After stirring for $2 \mathrm{~h}$, the reaction was quenched with $\mathrm{NH}_{4} \mathrm{Cl}(10 \mathrm{~mL}$, saturated aqueous solution), and the aqueous phase was extracted with $\mathrm{CH}_{2} \mathrm{Cl}_{2}(3 \times 25 \mathrm{~mL})$. The combined organic layer was dried with $\mathrm{Na}_{2} \mathrm{SO}_{4}$, and evaporated under reduced pressure. The product was purified by column chromatography on silica gel [hexane-EtOAc; (3:1)].

$\mathbf{N}, \mathbf{N}^{\prime}$-\{Di(propionyl)-di[(S)-1-phenylethyl]\}ethylenediamine (3a). The product was isolated in form of colorless crystalline powder. $\mathrm{mp} 69-71{ }^{\circ} \mathrm{C}$. $\left(0.45 \mathrm{~g}, 89 \%\right.$ yield). $[\alpha]_{\mathrm{D}}{ }^{20}-100.8$ (c $\left.1, \mathrm{CHCl}_{3}\right) .{ }^{1} \mathrm{H}$ NMR $\left(400 \mathrm{MHz}, \mathrm{CDCl}_{3}\right) \delta_{\mathrm{H}}$ 1.12 (t, J 7.4 Hz, 3H, H-3E), 1.19 (t, J 7.2 Hz, 3H, H-3Z), 1.38 (d, J $4.2 \mathrm{~Hz}, 3 \mathrm{H}, \mathrm{H}-\mathrm{H}^{\prime \prime}$ ), 1.41 (m, J $\left.4.0 \mathrm{~Hz}, 3 \mathrm{H}, \mathrm{H}-2^{\prime}\right)$, 1.74 (d, J $\left.7.0 \mathrm{~Hz}, 2 \mathrm{H}, \mathrm{H}-3 Z^{\prime}\right), 2.15$ (c, J $\left.7.4 \mathrm{~Hz}, 2 \mathrm{H}, \mathrm{H}-2 \mathrm{E}\right), 2.55$ (m, 2H, H-2Z), 2.75 (m, 2H, H-1a', H-1a”), 3.18 (m, 2H, H-1a', H1a"), 5.08 (c, J $\left.6.6 \mathrm{~Hz}, 1 \mathrm{H}, \mathrm{H}-1^{\prime \prime}\right), 5.92$ (c, J $\left.7.0 \mathrm{~Hz}, 1 \mathrm{H}, \mathrm{H}-1^{\prime}\right), 7.28(\mathrm{~m}, 10 \mathrm{H}) .{ }^{13} \mathrm{C} \mathrm{NMR} \mathrm{(100} \mathrm{MHz,}$ $\left.\mathrm{CDCl}_{3}\right) \delta_{\mathrm{C}} 9.4\left(\mathrm{CH}_{3}, \mathrm{C}-3 \mathrm{Z}\right), 9.8\left(\mathrm{CH}_{3}, \mathrm{C}-3 \mathrm{E}\right), 16.3\left(\mathrm{CH}_{3}, \mathrm{C}-2^{\prime}\right), 17.0\left(\mathrm{CH}_{3}, \mathrm{C}-2^{\prime \prime}\right), 18.0\left(\mathrm{CH}_{3}, \mathrm{C}-2^{\prime \prime \prime}\right), 25.7\left(\mathrm{CH}_{2}, \mathrm{C}-2 \mathrm{Z}\right)$, $26.6\left(\mathrm{CH}_{2}, \mathrm{C}-2 \mathrm{E}\right), 26.8\left(\mathrm{CH}_{2}, \mathrm{C}-2 E^{\prime}\right), 40.8\left(\mathrm{CH}_{3}, \mathrm{C}-1 \mathrm{a}^{\prime}\right), 41.1\left(\mathrm{CH}_{2}, 1 \mathrm{a}^{\prime \prime \prime}\right), 42.6\left(\mathrm{CH}_{2}, 1 \mathrm{a}^{\prime \prime}\right), 49.8\left(\mathrm{CH}, \mathrm{C}-1^{\prime}\right), 54.0(\mathrm{CH}$, C-1"), 54.9 ( $\left.\mathrm{CH}, \mathrm{C}-1^{\prime \prime \prime}\right), 126.2(\mathrm{Ar}-\mathrm{CH}), 126.5$ (Ar-CH), 126.7 (Ar-CH), $126.8(\mathrm{Ar}-\mathrm{CH}), 127.4(\mathrm{Ar}-\mathrm{CH}), 127.7(\mathrm{Ar}-\mathrm{CH})$, 128.0 (Ar-CH), 128.2 (Ar-CH),139.1 (C-ipso), 140.0 (C-ipso), 141.0 (C-ipso), 173.3 (CO), 174.0 (CO). Crystal suitable for single-crystal $\mathrm{X}$-ray diffraction analysis were grown from a solvent mixture ethanol and dichloromethane $(3: 1 \mathrm{v} / \mathrm{v})$. Crystal data for $\mathrm{C}_{24} \mathrm{H}_{32} \mathrm{~N}_{2} \mathrm{O}_{2}, \mathrm{Mr}=380.52,0.46 \times 0.52 \times 0.54 \mathrm{~mm}^{3}$, monoclinic, space group $\mathrm{P} 21, \mathrm{a}=8.9726(10) \AA, b=12.2364(14) \AA, c=10.1590(11) \AA, \beta=96.084(2)^{\circ}, V=1109.1(2) \AA 3, Z=2, \delta_{\text {calcd }}$ $=1.139 \mathrm{~g} / \mathrm{cm}^{3}, \mu=0.072 \mathrm{~mm}^{-1}, 2 \theta_{\max }=26,11639$ reflections collected, 2290 independent reflections $\left(R_{\text {int }}=\right.$ $0.0259), R_{1}=0.0443$ for 2290 reflections with $\mathrm{I}>2 \sigma(\mathrm{l})$ and $w \mathrm{R}_{2}=0.1186$ for all data, 257 parameters, GOF = 1.21. CCDC 1519415. $\mathrm{FAB}^{+}-\mathrm{MS} \mathrm{m} / \mathrm{z}$ found: 381.2541 [M] ${ }^{+}$(calcd. for $\mathrm{C}_{24} \mathrm{H}_{33} \mathrm{O}_{2} \mathrm{~N}_{2}$ 381.2542). Anal. calcd C, 75.75; $H, 8.48 ; N, 7.36$. Found: $C, 75.96 ; H, 8.68 ; N, 7.42$.

3,3'-Diphenyl- $N, N^{\prime}$-\{di(propionyl)-di[(S)-1-phenylethyl]\}ethylenediamine (3b). The product was recovered as a yellow liquid $(0.09 \mathrm{~g}, 91 \%)$. [ $\alpha]_{D^{20}}-185.7\left(c 0.5, \mathrm{CHCl}_{3}\right) .{ }^{1} \mathrm{H} \mathrm{NMR}\left(200 \mathrm{MHz}, \mathrm{CDCl}_{3}\right) \delta_{\mathrm{H}} 1.25(\mathrm{~d}, J 7.0 \mathrm{~Hz}, 3 \mathrm{H})$, $1.37(\mathrm{~d}, J 7.0 \mathrm{~Hz}, 3 \mathrm{H}), 1.66(\mathrm{~d}, J 7.0 \mathrm{~Hz}, 2 \mathrm{H}), 2.47(\mathrm{~m}, 3 \mathrm{H}), 2.63(\mathrm{~m}, 1 \mathrm{H}), 2.79(\mathrm{~m}, 3 \mathrm{H}), 2.96(\mathrm{~m}, 1 \mathrm{H}), 3.14(\mathrm{~m}, 6 \mathrm{H})$, $4.92(\mathrm{~m}, 2 \mathrm{H}), 5.89(\mathrm{c}, J 7.0 \mathrm{~Hz}, 1 \mathrm{H}), 6.9(\mathrm{~m}, 1 \mathrm{H}), 7.04(\mathrm{~m}, 1 \mathrm{H}), 7.20(\mathrm{~m}, 18 \mathrm{H}) .{ }^{13} \mathrm{C} \mathrm{NMR}\left(50 \mathrm{MHz}, \mathrm{CDCl}_{3}\right) \delta_{\mathrm{c}} 17.3$ $\left(\mathrm{CH}_{3}, \mathrm{C}-2^{\prime \prime}\right), 18.1\left(\mathrm{CH}_{3}, \mathrm{C}-2^{\prime}\right), 18.9\left(\mathrm{CH}_{3}, \mathrm{C}-2^{\prime \prime \prime}\right), 32.3\left(\mathrm{CH}_{2}, 1^{\prime \prime} \mathrm{a}\right), 32.4\left(\mathrm{CH}_{2}, 1^{\prime} \mathrm{a}\right), 34.5\left(\mathrm{CH}_{2}, 2 \mathrm{E}\right), 35.9\left(\mathrm{CH}_{2}, 2 \mathrm{Z}\right)$, $36.3\left(\mathrm{CH}_{2}, 2 Z^{\prime}\right), 41.7\left(\mathrm{CH}_{2}, 3 E\right), 42.1\left(\mathrm{CH}_{2}, 3 Z^{\prime}\right), 43.4\left(\mathrm{CH}_{2}, 3 Z\right), 50.9\left(\mathrm{CH}, 1^{\prime \prime}\right), 54.9\left(\mathrm{CH}, 1^{\prime}\right), 55.9\left(\mathrm{CH}, 1^{\prime \prime \prime}\right), 125.7$ (Ar-CH), 125.8 (Ar-CH), $125.9(\mathrm{Ar}-\mathrm{CH}), 126.5(\mathrm{Ar}-\mathrm{CH}), 126.7(\mathrm{Ar}-\mathrm{CH}), 126.9(\mathrm{Ar}-\mathrm{CH}), 127.1(\mathrm{Ar}-\mathrm{CH}), 127.5(\mathrm{Ar}-$ $\mathrm{CH}), 127.9$ (Ar-CH), 128.2 (Ar-CH), 128.3 (Ar-CH), 128.6 (Ar-CH), 139.0 (Ar-C), 140.5 (Ar-C), 140.8 (Ar-C), 140.9 (Ar-C), 171.5 (Ar-C), 172.3 (Ar-C). FAB ${ }^{+}-\mathrm{MS} \mathrm{m} / z$ found: 533.3176 [M] ${ }^{+}$calcd. for $\mathrm{C}_{36} \mathrm{H}_{41} \mathrm{O}_{2} \mathrm{~N}_{2}$ 533.3168. 
$\boldsymbol{N}, \boldsymbol{N}^{\prime}$-\{Di(benzoyl)-di[(S)-1-phenylethyl]\}ethylenediamine (3c). The product was isolated in form colorless crystalline powder. $\mathrm{mp} 135-137^{\circ} \mathrm{C} ;\left(0.86 \mathrm{~g}, 98 \%\right.$ yield). $[\alpha]_{\mathrm{D}}{ }^{20}-128.8$ (c 1, $\left.\mathrm{CHCl}_{3}\right) .{ }^{1} \mathrm{H} \mathrm{NMR}\left(200 \mathrm{MHz}, \mathrm{CDCl}_{3}\right) \delta_{\mathrm{H}}$ $1.28(\mathrm{~s} a, 3 \mathrm{H}), 3.29(\mathrm{~s} a, 2 \mathrm{H}), 5.10(\mathrm{~s} \mathrm{a}, 1 \mathrm{H}), 7.37(\mathrm{~m}, 10 \mathrm{H}) .{ }^{13} \mathrm{C} \mathrm{NMR}\left(50 \mathrm{MHz}, \mathrm{CDCl}_{3}\right) \delta_{c} 17.7\left(\mathrm{CH}_{3}\right), 40.9\left(\mathrm{CH}_{2}\right)$, 57.2 (CH), 126.39 (Ar-CH), 127.1 (Ar-CH), $127.6(\mathrm{Ar}-\mathrm{CH}), 128.2(\mathrm{Ar}-\mathrm{CH}), 128.6(\mathrm{Ar}-\mathrm{CH}), 128.7$ (Ar-CH), 129.4 (Ar$\mathrm{CH}), 129.4(\mathrm{Ar}-\mathrm{CH}), 137.0(\mathrm{Ar}-\mathrm{C}), 140.0(\mathrm{Ar}-\mathrm{C}), 172.4(\mathrm{Ar}-\mathrm{CH}) . \mathrm{FAB}^{+}-\mathrm{MS} \mathrm{m} / \mathrm{z}$ found: 477.2536 [M] $^{+}$calcd. for $\mathrm{C}_{32} \mathrm{H}_{33} \mathrm{O}_{2} \mathrm{~N}_{2} 477.2542$.

Single-crystal X-ray diffraction analysis. Single-crystal X-ray diffraction studies were performed on a BrukerAPEX diffractometer with a CCD area detector $\left(\lambda_{\text {MoK } \alpha}=0.71073 \AA\right.$, monochromator: graphite). Frames were collected at $T 293 \mathrm{~K}$ via $\omega / \varphi$-rotation at $10 \mathrm{~s}$ per frame (SMART). ${ }^{37}$ The measured intensities were reduced to $F^{2}$ and corrected for absorption with SADABS (SAINT-NT). ${ }^{38}$ Corrections were made for Lorentz and polarization effects. Structure solution, refinement and data output were carried out with the SHELXTL-NT program package. ${ }^{39,40}$ Non hydrogen atoms were refined anisotropically, while hydrogen atoms were placed in geometrically calculated positions using a riding model.

Crystallographic data for the structure reported in this paper have been deposited with the Cambridge Crystallographic Data Centre as supplementary publication no. CCDC-1489379-1489381. Copies of the data can be obtained free of charge on application to CCDC, 12 Union Road, Cambridge CB2 1EZ, UK (fax: (+44)1223-336-033; e-mail: deposit@ccdc.cam.ac.uk, website http://www.ccdc.cam.ac.uk).

Computational details. The geometries of all structures were fully optimized by using density functional theory (DFT) with the hybrid-functional B3LYP ${ }^{41,42}$ in combination with the $6-31 G(\mathrm{dp})^{43}$ basis set implemented in the Gaussian 09 software package. ${ }^{44}$ In order to characterize all structures as minima, their vibrational frequencies were calculated at the same level of theory. The Polarizable Continuum Model (PCM) ${ }^{45}$ was used to compute energies in chloroform and DMSO with electrostatic dielectric constants, $\varepsilon 4.9$ and $\varepsilon$ 46.7, respectively. This calculation was performed in the presence of a solvent by placing the solute in a cavity within the solvent reaction field via a set of overlapping spheres. Results were visualized with the Chemcraft program v1.6. The utility of the B3LYP functional for the theoretical characterization of organic systems has been widely explored in previous publications, showing good results. ${ }^{46}$

\section{Acknowledgements}

This work was supported by CONACYT, Consejo Nacional de Ciencia y Tecnología (Project No. V39500-Q and Student Grant No. 145001). The authors acknowledge access to Laboratorio Nacional de Estructura de Macromoleculas (LANEM).

\section{References}

1. Sharma, V.; Crankshaw, C. L.; Piwnica-Worms, D.; J. Med. Chem., 1996, 39, 3843.

2. Montalbetti, C. A. G. N.; Falque, V. Tetrahedron 2005, 61, 10827. https://dx.doi.org/10.1016/i.tet.2005.08.031

3. Valeur, E.; Bradley, M. Chem. Soc. Rev. 2009, 38, 606-631 https://www.ncbi.nlm.nih.gov/pubmed/19169468 
Arkivoc 2017, v, 89-99

4. Sage, C. R.; Micheltisch, M. D.; Stout, T. J.; Biermann, D.; Nissen, R.; Finer-Moore, J.; Stroud, R. M.; Biochemistry, 1998, 37, 13893-13901

https://pubs.acs.org/doi/abs/10.1021/bi9810510

5. Chang Fong, J.; Benamour, K.; Szymonski, B.; Thomasson, F.; Morand, J. M.; Cussac, M. Chem. Pharm. Bull., 2000, 48, 729.

https://doi.org/10.1248/cbp.48.729

6. Roughley, S. D.; Jordan, A. M. J. Med. Chem., 2011, 54, 3451.

https://pubs.acs.org/doi/abs/10.1021/im200187y

7. Pattabiraman, V. R.; Bode, J. W. Nature, 2011, 480, 471.

https://www.nature.com/nature/journal/v480/n7378/.../nature10702.html

8. Allen, C. L.; Williams, J. M. J. Chem. Soc. Rev., 2011, 40, 3405.

https://pubs.rsc.org/en/content/articlehtml/2011/cs/c0cs00196a

9. Valeur, E.; Bradley, M. Chem. Soc. Rev. 2009, 38, 606.

https://pubs.rsc.org/en/content/articlepdf/2009/cs/b701677h

10. Tang, P. Org. Synth., 2005, 81, 262.

http://onlinelibrary.wiley.com/doi/10.1002/0471264229.os081.28/

11. Charville, H.; Jackson, D.; Hodges, G.; Whiting, A. Chem. Commun., 2010, 46, 1813.

https://pubs.rsc.org/en/content/articlehtml/2010/cc/b923093a

12. Gunanathan, C.; Yehoshoa, B.-D.; Milstein, D. Science 2007, 317, 790.

https://www.ncbi.nlm.nih.gov/labs/articles/17690291

13. Soule, J.-F.; Miyamura, H.; Kobayashi, S. J. Am. Chem. Soc. 2011, 133, 18550.

https://pubs.acs.org/doi/abs/10.1021/ja2080086

14. Kegnæs, S.; Mielby, J.; Mentzel, U. V.; Jensen, T.; Fristrup, P.; Riisager, A. Chem. Commun. 2012, 48, 2427 https;//pubs.rsc.org/en/content/articlehtml/2012/cc/c2cc16768a

15. Martinelli, J. R.; Clark, T. P.; Watson, D. A.; Munday, R. H.; Buchwald, S. L. Angew. Chem., Int. Ed. 2007, 46, 8460.

http://onlinelibrary.wiley.com/doi/10.1002/anie.200702943/full

16. Brennführer, A.; Neumann, H.; Beller, M. Angew. Chem., Int. Ed. 2009, 48, 4114.

http://onlinelibrary.wiley.com/doi/10.1002/anie.200900013/full

17. Cho, S.; Yoo, E.; Bae, I.; Chang, S. J. Am. Chem. Soc. 2005, 127, 16046.

https://pubs.acs.org/doi/abs/10.1021/ja056399e

18. Chen, Z.-W.; Jiang, H.-F.; Pan, X.-Y.; He, Z.-J. Tetrahedron 2011, 67, 5920. https://dx.doi.org/10.1016/i.tet.2011.06.045

19. Eldred, S. E.; Stone, D. A.; Gellman, S. H.; Stahl, S. S. J. Am. Chem. Soc. 2003, 125, 3422. https://pubs.acs.org/doi/abs/10.1021/ja028242h

20. Zhang, M.; Imm, S.; Bähn, S.; Neubert, L.; Neumann, H.; Beller, M. Angew. Chem., Int. Ed. 2012, 51, 3905 http://onlinelibrary.wiley.com/doi/10.1002/anie.201108599/full

21. Nakagawa, K.; Inoue, H.; Minami, K. Chem. Commun. 1966, 17.

22. Ekoue-Kovi, E.; Wolf, C. Chem. A Eur J. 2008, 14, 6302 http://onlinelibrary.wiley.com/doi/10.1002/chem.200800353/full

23. Fife, T. H.; Perillo, A. M.; J. Am. Chem. Soc. 1980, 3062. http://pubs.acs.org/doi/abs/10.1021/ja00529a032

24. Wüthrich, K. NMR in Biological Research: Peptides and Proteins, North Holland, Amsterdam, 1976, pp. $73-$ 184. 
25. Lefrançois, L.; Hébrant, M.; Tondre, C Delpuech, J.-J.; Berthon, C.; Madic, C. J. Chem. Soc., Perkin Trans. 2, 1999, 1149-1158

https://pubs.rsc.org/en/content/articlehtml/1999/p2/a900766k

26. Mastranzo, V. M.; Quintero, L.; de Parrodi, C. A.; Juaristi, E.; Walsh, P. J. Tetrahedron, 2004, 60, 1781. http://dx.doi.org/10.1016/j.tet.2003.12.039

27. Moreno, G. E.; Quintero, L.; Bernès, S.; de Parrodi, C. A. Tetrahedron Lett., 2004, 45, 4245. http://dx.doi.org/10.1016/j.tetlet.2004.04.027

28. Horner, L.; Dickerhof, L. Liebigs Ann. Chem., 1984, 124

29. Coldham, I.; Houndayer, A.; Judkings, R. A.; Witty, D. R. Tetrahedron, 1998, 54, 14255. http://dx.doi.org/10.1016/S0040-4020(98)00877-1

30. Kise, N.; Urai, T.; Yoshida, J. Tetrahedron: Asymmetry, 1998, 9, 3125. http://dx.doi.org/10.1016/S0957-4166(98)00319-X

31. Dalko, P. I.; Langlois, Y. J. Org. Chem., 1998, 63, 8107. http://pubs.acs.org/doi/abs/10.1021/j0980289r

32. Bailey, W. F.; Beak, P.; Kerrick, S. T.; Ma, S.; Wiberg, K. J. Am. Chem. Soc., 2002, 124, 1889. http://pubs.acs.org/doi/abs/10.1021/ja012169y

33. Sélambaron, J.; Monge, S.; Carré, F.; Roque, J. P.; Pavia, A. A. Tetrahedron, 2002, 58, 9559. http://dx.doi.org/10.1016/S0040-4020(02)01287-5

34. Sandoval-Lira J.; Fuentes, L.; Quintero, L.; Höpfl, H.; Hernández-Pérez, J. M.; Terán, J. L.; Sartillo-Piscil, F. J. Org. Chem., 2015, 80, 4481-4490 http://pubs.acs.org/doi/abs/10.1021/acs.joc.5b00286

35. Juaristi, E. Introduction to Stereochemistry and Conformational Analysis, Wiley: New York, NY, 1991.

36. Oki, M. Application of Dynamic NMR Spectroscopy to Organic Chemistry; Wiley-VCH:Weinheim, 1985

37. SMART. Bruker Molecular Analysis Research Tool, versions 5.057 and 5.618; Bruker Analytical X-ray Systems Inc.: Madison, Wisconsin, USA, 1997 and 2000.

38. SAINT+NT. Data Reduction Software, versions 6.01 and 6.04; Bruker Analytical X-ray Systems Inc.: Madison, Wisconsin, USA, 1999 and 2001.

39. Sheldrick, G. M. Foundations of Crystallography. Acta Cryst. A 2008, 64, 112-122.

40. SHELXTL-NT. Crystal Structure Analysis Package, versions 5.10 and 6.10; Bruker Analytical X-ray Systems Inc.: Madison, Wisconsin, USA, 1999 and 2000.

41. Becke, A. D. J. Am. Chem. Phys. 1993, 98, 5648. http://dx.doi.org/10.1063/1.464913

42. Lee, C.; Yang, W.; Parr, R. G. Phys. Rev. B, 1988, 37, 785. https://doi.org/10.1103/PhysRevB.37.785

43. Weigend, F.; Ahlrichs, R. Phys. Chem. Chem. Phys., 2005, 7, 3297-3305 http://pubs.rsc.org/en/content/articlehtml/2005/cp/b508541a 
44. Frisch, M. J.; Trucks, G. W.; Schlegel, H. B.; Scuseria, G. E.; Robb, M. A. Cheeseman, J. R.; Scalmani, G.; Barone, V.; Mennucci, B.; Petersson, G. A.; Nakatsuji, H.; Caricato, M.; Li, X.; Hratchian, H. P.; Izmaylov, A. F.; Bloino, J.; Zheng, G.; Sonnenberg, J. L.; Hada, M.; Ehara, M.; Toyota, K.; Fukuda, R. Hasegawa, J.; Ishida, M.; Nakajima, T.; Honda, Y.; Kitao, O.; Nakai, H.; Vreven, T.; Montgomery, J. A.; Peralta, Jr., J. E.; Ogliaro, F.; Bearpark, M.; Heyd, J. J.; Brothers, E.; Kudin, K. N.; Staroverov, V. N.; Kobayashi, R.; Normand, J.; Raghavachari, K.; Rendell, A.; Burant, J. C.; Iyengar, S. S.; Tomasi, J.; Cossi, M.; Rega, N.; Millam, M. J.; Klene, M.; Knox, J. E.; Cross, J. B.; Bakken, V.; Adamo, C.; Jaramillo, J.; Gomperts, R.; Stratmann, R. E.; Yazyev, O.; Austin, A. J.; Cammi, R.; Pomelli, C.; Ochterski, J.W.; Martin, R. L.; Morokuma, K.; Zakrzewski, V. G.; Voth, G. A.; Salvador, P.; Dannenberg, J. J.; Dapprich, S.; Daniels, A. D.; Farkas, Ö.; Foresman, J. B.; Ortiz, J. V.; Cioslowski, J.; Fox, D. J. Gaussian 09, Revision B.01, Gaussian, Inc., Wallingford CT, 2009.

45. Tomasi, J., Mennucci, B., Cammi, R., Chem. Rev. 2005, 105, 2999-3094 http://pubs.acs.org/doi/abs/10.1021/cr9904009

46. Huelgas, G.; Bernès, S.; Sánchez, M.; Quintero, L.; Juaristi, E.; Anaya de Parrodi, C.; Walsh, P. J. Tetrahedron 2007, 63, 12655-12664 http://dx.doi.org/10.1016/j.tet.2007.10.010 